Cheyne-Stokes character, and it was evident to all that unless some change took place he would speedily sink. Bearing in mind the somewhat distended state of his bloodvessels, I determined to perform venesection, and my brother, Mr. D. F. Whiteley, who now saw the case in consultation with me, at once agreed that bleeding offered the only means of saving his life. In order to see what would be the effect of gradual depletion, we applied ten leeches to his head; relief was at once apparent, respiration became normal, and on speaking to him he opened his eyes and appeared somewhat conscious. Unfortunately this con dition was not of long duration, for in an hour respiration had once more assumed the Cheyne-Stokes type, and it was impossible to get any sign of recognition. Arguing from this that if more blood were withdrawn the improvement would be more lasting, I opened the vein in his left arm and bled to the amount of ten ounces; the effect of this was simply marvellous, for he at once became conscious and recognized a brother who had come a long distance to see him, and who, before the operation, was deeply grieved at not being able to obtain any response. For the following eight. days recovery was uninterrupted, he regained consciousness, and was able to be moved from one bed to another. On my next visit, however, I was surprised to find him again complaining of occipital headache, and apparently very drowsy; this condition gradually increased, and he relapsed into a state of profound coma and appeared as bad or even worse than at first. With such a condition of things it seemed to me that a repetition of my former treatment was the only line to follow, so I applied several leeches to his temples; and from that moment improvement gradually became manifest, he made an excellent recovery, and is now, as he says, as well as ever he was in his life, and able to do a day's work.

Remarks - The above case affords a brilliant illustration of the immediate effect of bleeding, for there is every reason to believe that without it he must very quickly have succumbed. I hesitated to bleed a second time, for his general condition, more especially that of his bloodvessels, rather contraindicated such a proceeding. However, it was done as a last resource, and happily proved successful. Years ago many people were bled regularly every spring in order to keep well, and very probably owing to its being done indiscriminately it fell into disfdvour; but there can be no doubt that it is a very potent remedy, and, in properly selected cases, an ever-ready means of combating disease when drugs are absolutely useless.

Downton, Salisbury.

\section{PRIMARY CATARRHAL SYPHILIS.}

\section{By Edward Frazer, L.R.C.P. \& S.}

Perhaps some of the readers of The Lancet may feel interested in the following peculiar case.

Towards the end of July I was consulted by a young man aged twenty years, for a discharge from the urethra. The discharge was profuse and of a purulent character, with scalding during micturition. None of the glands was enlarged. He at once admitted having had connexion three weeks previously with a woman in a certain garrison town some miles distant. I prescribed an injection of subacetate of lead, and in two weeks the discharge had quite ceased, and the patient declared that he felt quite well. thought nothing more of the case until a month later, when the patient returned complaining of sore-throat and a rash over the body. The rash was distinctly syphilitic, and the throat bore all the characteristics of that disease. I closely questioned the patient, who steadfastly denied ever having had connexion save on that one occasion. On examining the penis I failed to detect any trace whatever of a cicatrix or induration. administered red iodide of mercury, iodide of potash, and bark. In a fortnight the hair fell off the eyebrows. After this the rash gradually disappeared, the throat got well, and the patient to all appearances regained his usual health.

This is the first case I have ever seen in which syphilis developed itself without a primary sore, and, taking everythirg into consideration, I am loth to conclude that a chancre existed in the urethra. Rather do I incline to the belief that it is one of those cases of "primary catarrhal syphilis" described by the late Mr. Morgan of Dublin, and reference to which I have not come across in any standard work on the subject.

Riverstown, Sligo.

\section{8. altituror}

\section{HOSPITAL PRACTICE,}

\section{BRITISH AND FOREIGN.}

Nulla autem est alia pro certo noscendi via, nisi quamplurimas et mors borum et dissectionum historias, tum aliorum tum proprias collectas habere, et inter se comparare.-MoRGaGNI De Sed. et Caus. Morb.o b. iv. Procmium.

\section{WEST LONDON HOSPITAL.}

A CASE OF GOUTY PERIOSTITIS.

(Under the care of Dr. GARROD.)

IN favour of the gouty origin of periostitis were the sudden onset of the attack, absence of any other recognised cause, the season of the year, the character of the pain and the appearance of the part, the cdema of the surrounding parts, and the rapidity with which the inflammation yielded to the treatment adopted. It should be mentioned that the patient, who has had a considerable experience of gouty attacks, stated that the pain was of the same nature as that which he had always experienced, and he volun. teered his conviction that this was an attack of gout. On the other hand, there was an entire absence of articular affections; and it would appear that periostitis is rarely met with either in association with uratic arthritis or as an isolated gouty lesion. During a somewhat ex. tended search through the literature of the subject, Mr. Alderson has failed to find any record of such a case as that described, although the occasional implication of the periosteum is mentioned by a few authors. However, the fact that uratic deposits in the periosteum are sometimes found post mortem suggests that such deposits probably bave their origin in such attacks as that from which J. R-was suffering when he presented himself at the hospital. For the notes of this case we are indebted to Mr. F. Herbert Alderson, house physician.

$J . R-$, a gardener, aged fifty-three, attended at the medical casualty department of the West London Hospital on March 21st, 1891. He stated that after walking a considerable distance in the earlier part of the day he was seized with pain in the left ankle and in the lower third of the leg. The pain commenced gradually, but soon became so intense that he was unable to walk any longer, and he came to the hospital.

On examination, a swelling was found over the internal aspect of the lower third of the left tibia, which had all the characters of a periosteal node. The part was hot, tender, and painful, and the skin over and around the swelling was red and odematous. The ankle-joint was in no way involved. Careful inquiry failed to elicit any history of injury. The patient denied syphilis, and there was no history of rash, sore-throat, loss of hair, sore tongue, gummata, or of any of the various secondary or tertiary manifestations of that disease. He is a married man, and his wife and nine children are all healthy. He gave a strong family history of gout, to which disease his father was a victim all his life. Three brothers and one sister have suffered from gouty attacks. He gave neither personal nor family history of rheumatism. The patient's first attack of gout dates from fifteen years ago, and on that occasion one of his ankles, after much walking, was affected. He has suffered from several subsequent attacks, in which the tarso-metatareal joint of both great toes, the knees, right ankle, and, in a less degree, the carpo-metacarpal joints, have been involved. His com. plexion is florid, and he suffers from acne rosacea. He has been accustomed to drink beer freely all his life, taking usually five or six pints a day. His pulse was regular, infrequent, and of high tension. He complained of dys. pepsia. The heart and lungs showed nothing abnormal. There were no tophi in the ears.

The diagnosis of gouty periostitis was made, and he was treated accordingly, being given ten minims of vinum colchici, five grains of iodide of potassium, ten grains of bicarbonate of potash, and an ounce of simple infusion of gentian, every four hours. Lead and opium lotion was applied locally, and the patient was instructed to attend as an out-patient on the following day under Dr. A. E. Garrod.

When he was seen by Dr. Garrod on the 22nd the pair 